\title{
Clio
}

Women, Gender, History

$40 \mid 2014$

Making Gender with Things

\section{On the Gender Bazaar}

Interview with Denis Chevallier

À propos du bazar du genre... Entretien avec Denis Chevallier

Leora Auslander, Michelle Zancarini-Fournel and Denis Chevallier

Translator: Anne Epstein

\section{(2) OpenEdition}

\section{Journals}

Electronic version

URL: http://journals.openedition.org/cliowgh/725

DOI: $10.4000 /$ cliowgh.725

ISSN: 2554-3822

\section{Publisher}

Belin

\section{Electronic reference}

Leora Auslander, Michelle Zancarini-Fournel and Denis Chevallier, « On the Gender Bazaar », Clio

[Online], 40 | 2014, Online since 15 April 2015, connection on 01 May 2019. URL : http:// journals.openedition.org/cliowgh/725; DOI : 10.4000/cliowgh.725 


\section{Testimony}

\section{On the Gender Bazaar}

Denis CHEVALLIER, curator of the exbibition "At the Bazaar of Gender, Feminine-Masculine in the Mediterranean" and Director of Research and Education at Marseille's Museum of European and Mediterranean Civilizations (MuCEM), spoke with Leora AUSLANDER and Michelle ZANCARINIFOURNEL on 8 December 2013, after taking them on a tour of the exhibition.

The exhibition, which closed on 6 January 2014, resulted in two publications, a volume co-authored by Denis Chevallier, Michel Bozon, Michelle Perrot, and Florence Rochefort and a short exhibition catalogue. ${ }^{1}$ The cover illustration on both features a woman "torera" in a toreador costume and red high heels, her left arm around a pressure cooker and her right hand gripping the handle of a sword: this self-portrait by Pilar Albarracin is an ironic nod to the advances women have made in the professions and other masculine domains (bullfighting) while still putting up with the daily grind (the pressure cooker).

In his introduction, entitled "Gender on display at the Museum of Civilizations", Denis Chevallier explains the decision to produce an exhibition for the inauguration of this "great museum, the MuCEM" that "would bring a Mediterranean dimension into contemporary debates on gender issues" ${ }^{2}$. In his view, the museography of gender - essentially concerned with rural societies - has focused too narrowly on romantic and marital

1 Denis Chevallier, Michel Bozon, Michelle Perrot \& Florence Rochefort (eds), Au Bazar du genre. Féminin/masculin en Méditerranée, Marseille, MuCEM, 2013. And with the same title and cover, a 48-page mini-catalogue.

2 Ibid.: 18-29. 
relations and marriage rituals, using "a simplified chronology that moves from 'courtship' to 'starting a family", avoiding issues of sexuality and kinship. References to gender began to appear in contemporary art museums at the end of the 1960s, with the presentation of works by artists such as Niki de Saint Phalle and Louise Bourgeois. More audacious, activist initiatives brought the creation of museums of women and museums of homosexuality in Europe in the 1970s (the one in Berlin opened in 1985). The classic account of the role of gender through history begins with early representations of masculinity and femininity (cave paintings or Neolithic so-called "Venus" figurines) and then, for the Mediterranean region, moves on to the three monotheistic religions and the legal codes - from the Code of Hammurabi (1750 B.C.) to modern civil codes and contemporary family law.

\section{So which are the "objects that tell about gender"?}

A wide range of objects could be related to the various themes, from clothing and accessories to objects associated with sexuality, procreation, and body care, different visual representations from photography to television, or even ritual objects. The aim of the exhibition was to highlight the changes in contemporary Mediterranean societies, particularly with respect to the body and sexualities, along with issues of equality and minorities in the public and private spheres. Although in the Mediterranean context, issues of violence against women, identity-based tensions and "traditional" values, such as the sacredness of female virginity, are important, to avoid reinforcing existing perceptions the exhibition focused on actors and vectors of change, and on the dynamics and circulation of experiences. It made use of media not often present in museums, such as television, webpages and videos, and works, installations, and performances by contemporary artists. Centering on the body and sexualities, the exhibition left little space for politics, so feminism is not emphasized. The "apparent disorder" of this gender bazaar "hides a certain sexual order" that the exhibition and the two publications attempt to reveal. Our discussion with Denis Chevallier provides further insight into some of these issues. 


\section{How did the exhibition originate?}

Denis Chevallier: We wanted to provide a close-up of Mediterranean culture and civilization through two exhibitions, one of photographs related to immigration, building on notions of putting down roots and being uprooted and drawing attention to inequalities in North/South relations; and the other on the place of women in Mediterranean societies through the lens of gender and sexuality, at a time when gay marriage ["le mariage pour tous"] was being debated in France. Raising questions that engage with the present is part of the curator's work.

\section{What was the connection with the former Museum of Popular Arts and Traditions in Paris (MNATP)?}

D.C.: Françoise Loux and an MNATP team had carried out a major campaign to collect objects and posters related to the AIDS epidemic (18 000 pieces). In 2003, the decision was made to transfer the MNATP collections to Marseille. A building was constructed behind the Saint-Charles Station specifically to receive the collections. For this exhibition, I also got in touch with other museums, with the Bibliothèque Marguerite Durand (in the $13^{\text {th }}$ arrondissement of Paris), and with Planned Parenthood, and I purchased some items via Internet (such as an artificial hymen).

\section{Did the exhibition cause any controversy when it opened?}

D.C.: I should first explain that it was quite a small exhibition (600 $\mathrm{m}^{2}$ of the $3,500 \mathrm{~m}^{2}$ of exhibition space), supplemented with a lecture series, guided tours and public debates. Visitors had access to a mini-catalogue, detailed interpretive labels and audio guides. Half of the visitors came from Marseille itself, 20\% from abroad, and the rest from the surrounding region or other parts of France. Clearly an exhibition that uses a specific vocabulary and appeals to people's sensibilities and to the spectacular may cause a bit of Benjaminian shock, as when history meets memory. But certain objects were seen more as curiosities, like the "pisse-debout", or female urinal, and the short film that went with it. 


\section{Was there any debate within your team?}

D.C.: There was a lot of discussion with our scientific board. In retrospect, we didn't place enough emphasis on transgender people the textbook case in "gender studies" - beyond the fantasy of the pregnant man: in an engraving of la cowvade, or sympathetic pregnancy, the father exhibits physical symptoms of pregnancy as a way of laying claim to the baby. We dealt very little with issues of family and descent. We preferred not to adopt a northern European "gender studies" perspective, which would have seemed out of place, preferring a more pragmatic, southern approach, that is, focused on violence against women, contraception, the wearing of headscarves, etc.

\section{There isn't much on the gender of work, is there?}

D.C.: We tried unsuccessfully to find fighter pilot uniforms. We opted to compile statistics on the number of women firefighters, women who attained the rank of general...

\section{Which objects tell viewers the most about gender?}

D.C.: It's a mixed bag: works on the wearing of the veil (filmed performances) say a lot and the pisse-debout is very effective also; the section on feminism doesn't work as well. Perhaps there weren't enough objects?

At the MNATP, the objects embodied the spirit of the museum and the curators were slaves to the objects. I want to reverse this concept and make the objects slaves to the curators. There are 350 items in this exhibition: $1 / 3$ come from the collections, $1 / 3$ are on loan, $1 / 3$ were made or ordered by us. The museographical language and the scenography of the exhibition have to correspond with the objects. The objects have equal significance for the exhibition, whether we're talking about a representation of homosexuality from the fourth century B.C. on loan from the Louvre, or a cotton T-shirt that reads " $100 \%$ single", bought over the Internet. Posters and objects have been redirected from their original purposes and messages towards a new end, fighting different forms of discrimination. 


\section{The exhibition's scenography has a raw feel to it. We imagine that's intentional?}

D.C.: Yes. For example, a large X-shaped display made of unfinished timber represents the structure of the exhibition, with 5 sets of themes arranged in pods on the arms of the $\mathrm{X}$, as follows:

$1-$ My womb belongs to me

2 - Progressing towards equality

3 - LGBT: living out one's difference

$4-$ My prince will come

5 - To each, his [sic] gender!

This last section contains the two great discoveries of the exhibition. The "Sworn Virgins of Albania" are single women who, having been legally recognized as men, adopted masculine dress and appearance. They were allowed to take on men's roles on condition that they remain virgins for life.

The "pregnant man" is a person who was female at birth and officially became a man through breast reduction and testosterone injections. Having kept his female sexual organs, this transgender individual was able to give birth to three children.

\section{How did the public react to the exhibition?}

D.C.: The exhibition was an overwhelming success (400,000 visitors in 7 months). By chance it happened to open right in the midst of the political debates and demonstrations about gay marriage, which as we know, contributed to complete polarization of public opinion about gender. The exhibition visitors' book, an immediate record of the public's impressions, provides solid evidence of this coincidence. Here, visitors with sharply contrasting opinions engaged in polemics and name-calling. The visitors' book is currently being analyzed by a research team at the University of AixMarseille, which also observed members of the public, both women and men, at the event. For many, the exhibition appeared as a major happening, offering the opportunity to question dominant ideas about women and men. But opponents of what polemicists have labeled "the theory of gender" criticize in the visitors' book what they see as misuse of public funds to call the family into question 
and glorify homosexuality. So the exhibition certainly sparked debate! 